\title{
How Relationship of Urine Bilirubin with Wrist-Watch Lovers?
}

\author{
Muhammad Imran Qadir, Taiba Akmal and Adnan Bukhari* \\ Institute of Molecular Biology and Biotechnology, Bahauddin Zakariya University of Multan, Pakistan \\ *Corresponding author: Adnan Bukhari, Institute of Molecular Biology and Biotechnology, Bahauddin Zakariya University of \\ Multan, Pakistan
}

\begin{tabular}{|c|c|}
\hline ARTICLE INFO & ABSTRACT \\
\hline Received: 慧 February 06, 2020 & Objective of the here studies was to correlation the urine bilirubin with wrist-watch \\
\hline Published: 㹃 February 14, 2020 & $\begin{array}{l}\text { likeliness. A total strength of } 200 \text { performers were performed. All students belong to } \\
\text { the institute of Molecular Biology and Biotechnology Bahauddin Zakariya University of }\end{array}$ \\
\hline $\begin{array}{l}\text { Citation: Muhammad Imran Qadir, Taiba } \\
\text { Akmal, Adnan Bukhari. How Relationship of } \\
\text { Urine Bilirubin with Wrist-Watch Lovers?. }\end{array}$ & $\begin{array}{l}\text { Multan Pakistan. To measure the urine bilirubin and questionnaire was precipitation } \\
\text { relation to urine bilirubin and their high interest if wrist-watch likeliness. In the here } \\
\text { study was both male and female. } 120 \text { females and } 80 \text { male performances in this project. } \\
\text { Most of the performers } 60-100 \text { have higher like of wrist-watch likeliness. While most } \\
\text { students } 40-100 \text { not interest the wrist-watch likeliness. }\end{array}$ \\
\hline
\end{tabular}

Biomed J Sci \& Tech Res 25(4)-2020. BJSTR. MS.ID.004230.

Keywords: Urine Bilirubin; Red Blood Cells; Urine Test; Liver

\section{Introduction}

Liver damage the substance causes the diseases is known as bilirubin. This diseases blood lake through the urine. Urine bilirubin have infections the urinary tract. Urine bilirubin have presented the young in 245-345 in per day. Its color has yellow. Liver damaged the diseases have hepatitis. Liver diseases detected by the liver test and high levels of bilirubin causes infection. Normal bilirubin does not cause any infection but high level of bilirubin causes the human skin or eyes yellow in color. High level of bilirubin causes the broken of red blood cells. High level of bilirubin causes the drugs and caffeine. Prevent the drugs low level of blood bilirubin. Test to detect the blood bilirubin present in the urine. Bilirubin have also the damage substances of liver and broken the red blood cells. Wristwatch is also used as the time. According to the management of work. To less time required seethe watch. Modern design and technology have introduced the new wristwatch have minimum work of phones. Electronics wristwatch used the multimedia like as Facebook, what's up, Skype etc.

\section{Material and Methods}

Total 200 performers were worked in this study. These subjects were designed workers of BZU of Multan in Pakistan. In the urine bilirubin have present to check the urine test. And find the level of bilirubin in urine to detected by the urine test and find the correct value of bilirubin. Urine bilirubin testing by the urine test and have the yellowish color or caused by the liver or skin.

\section{Project Design}

A questionnaire was performed by the wrist-watch likeliness. And have higher like of wrist-watch likeliness but lower percentage of students don't like wristwatch.

\section{Statistical Analysis}

We precipitated statistical using by the Microsoft excel.

\section{Result and Discussion}

In the specific amount of the urine of bilirubin present the $58 \%$ of the higher liked the wristwatch loving. While less amount of the $11 \%$ not interested in the wristwatch loving. In the urine present the bilirubin amount to check the urine test and have detected the causes of the kidney infection. Questionnaire was prepared by higher students choose the wristwatch lovers (Table 1). 
Table 1: Means values of the wristwatch loving.

\begin{tabular}{|c|c|c|}
\hline & Wristwatch likes & Wristwatch dislikes \\
\hline Male & $42 \%$ & $58 \%$ \\
\hline Female & $53 \%$ & $47 \%$ \\
\hline
\end{tabular}

\section{Conclusion}

It was concluded that the current study was to correlation the student's higher interests of wrist-watch lovers.

\section{References}

1. Qadir MI, Malik SA (2010) Comparison of alterations in red blood cel count and alterations in hemoglobin concentration in patients suffering from rectal carcinoma undergoing 5 -fluorouracil and folic acid therapy. Pharmacologyonline 3: 240-243.

2. Qadir MI, Noor A (2018) Anemias. Rare \& Uncommon Diseases. Cambridge Scholars Publishing. Newcastle, England, ISBN: 978-1-52751807-0.

ISSN: 2574-1241

DOI: $10.26717 /$ BJSTR.2020.25.004230

Adnan Bukhari. Biomed J Sci \& Tech Res

CC (9) This work is licensed under Creative

Submission Link: https://biomedres.us/submit-manuscript.php
3. Qadir MI, Javid A (2018) Awareness about Crohn's Disease in biotechnology students. Glo Adv Res J Med Medical Sci 7(3): 062-064.

4. Qadir MI, Saleem A (2018) Awareness about ischemic heart disease in university biotechnology students. Glo Adv Res J Med Medical Sci 7(3): 059-061.

5. Qadir MI, Ishfaq S (2018) Awareness about hypertension in biology students. Int J Mod Pharma Res 7(2): 08-10.

6. Qadir MI, Mehwish (2018) Awareness about psoriasis disease. Int J Mod Pharma Res 7(2): 17-18.

7. Qadir MI, Shahzad R (2018) Awareness about obesity in postgraduate students of biotechnology. Int J Mod Pharma Res 7(2): 14-16.

8. Qadir MI, Rizvi M (2018) Awareness about thalassemia in post graduate students. MOJ Lymphology \& Phlebology 2(1): 14-16.

9. Qadir MI, Ghalia BA (2018) Awareness survey about colorectal cancer in of M. Phil Biotechnology at Bahauddin Zakariya University, Multan, Pakistan. Nov Appro in Can Study 1(3).

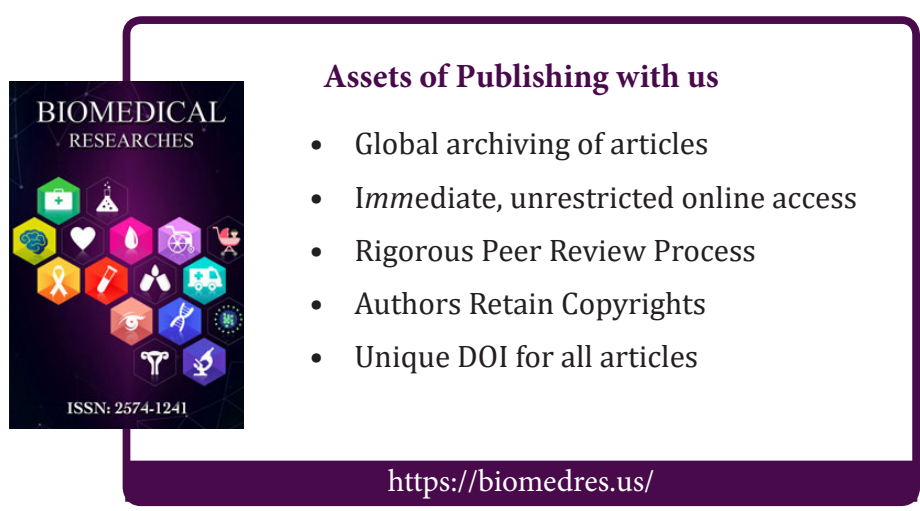

